University of Nebraska - Lincoln

DigitalCommons@University of Nebraska - Lincoln

July 2002

\title{
BEAVER HERBIVORY AND ITS EFFECT ON COTTONWOOD TREES: INFLUENCE OF FLOODING ALONG MATCHED REGULATED AND UNREGULATED RIVERS
}

\author{
Stewart W. Breck \\ USDA/APHIS/WS National Wildlife Research Center, stewart.w.breck@aphis.usda.gov \\ Kenneth R. Wilson \\ Colorado State University, kenneth.wilson@colostate.edu \\ Douglas C. Andersen \\ United States Geological Survey
}

Follow this and additional works at: https://digitalcommons.unl.edu/icwdm_usdanwrc

Part of the Environmental Sciences Commons

\begin{abstract}
Breck, Stewart W.; Wilson, Kenneth R.; and Andersen, Douglas C., "BEAVER HERBIVORY AND ITS EFFECT ON COTTONWOOD TREES: INFLUENCE OF FLOODING ALONG MATCHED REGULATED AND UNREGULATED RIVERS" (2002). USDA National Wildlife Research Center - Staff Publications. 82. https://digitalcommons.unl.edu/icwdm_usdanwrc/82
\end{abstract}

This Article is brought to you for free and open access by the U.S. Department of Agriculture: Animal and Plant Health Inspection Service at DigitalCommons@University of Nebraska - Lincoln. It has been accepted for inclusion in USDA National Wildlife Research Center - Staff Publications by an authorized administrator of DigitalCommons@University of Nebraska - Lincoln. 


\title{
BEAVER HERBIVORY AND ITS EFFECT ON COTTONWOOD TREES: INFLUENCE OF FLOODING ALONG MATCHED REGULATED AND UNREGULATED RIVERS
}

\author{
STEWART W. BRECK, ${ }^{a *}$ KENNETH R. WILSON ${ }^{\mathrm{a}}$ and DOUGLAS C. ANDERSEN ${ }^{\mathrm{b}}$ \\ a Department of Fishery and Wildlife Biology, Colorado State University, Fort Collins, CO 80523, USA \\ b United States Geological Survey, D-8220, PO Box 25007, Denver, Colorado 80225, USA
}

\begin{abstract}
We compared beaver (Castor canadensis) foraging patterns on Fremont cottonwood (Populus deltoides subsp. wislizenii) saplings and the probability of saplings being cut on a $10 \mathrm{~km}$ reach of the flow-regulated Green River and a $8.6 \mathrm{~km}$ reach of the free-flowing Yampa River in northwestern Colorado. We measured the abundance and density of cottonwood on each reach and followed the fates of individually marked saplings in three patches of cottonwood on the Yampa River and two patches on the Green River. Two natural floods on the Yampa River and one controlled flood on the Green River between May 1998 and November 1999 allowed us to assess the effect of flooding on beaver herbivory. Independent of beaver herbivory, flow regulation on the Green River has caused a decrease in number of cottonwood patches per kilometre of river, area of patches per kilometre, and average stem density within cottonwood patches. The number of saplings cut per beaver colony was three times lower on the Green River than on the Yampa River but the probability of a sapling being cut by a beaver was still higher on the Green River because of lower sapling density there. Controlled flooding appeared to increase the rate of foraging on the Green River by inundating patches of cottonwood, which enhanced access by beaver. Our results suggest regulation can magnify the impact of beaver on cottonwood through interrelated effects on plant spatial distribution and cottonwood density, with the result that beaver herbivory will need to be considered in plans to enhance cottonwood populations along regulated rivers. Published in 2002 by John Wiley \& Sons, Ltd.
\end{abstract}

KEY WORDS: Castor canadensis; Flaming Gorge Dam; flooding; flow regulation; Green River; herbivory; Populus deltoides; Yampa River

\section{INTRODUCTION}

Cottonwood (Populus spp.) forests along aridland rivers of the western USA are often a critical and irreplaceable component of riparian ecosystems (Knopf et al., 1988; Gregory et al., 1991; Braatne et al., 1996). Flow modification due to the diversion of water and operation of large dams is partially responsible for a drastic decline in cottonwood recruitment along many of these rivers (Reily and Johnson, 1982; Fenner et al., 1985; Howe and Knopf, 1991; Snyder and Miller, 1992; Rood and Mahoney, 1995; Busch and Smith, 1995; Braatne et al., 1996; Cooper et al., 1999). Both biotic and abiotic processes are involved in the decline, (Braatne et al., 1996; Scott et al., 1996), but most research has focused on abiotic alterations that influence the earliest stages (seed germination and seedling survival) of cottonwood recruitment (Bradley and Smith, 1986; Stromberg et al., 1991; Segelquist et al., 1993; Scott et al., 1997; Cooper et al., 1999). Biotic factors that influence cottonwood recruitment under a flow-regulated regime remain poorly understood but are potentially important, particularly in terms of restoration of cottonwood gallery forests (Braatne et al., 1996; Andersen and Cooper, 2000).

Herbivory is a biotic factor that plays an important role in the structure and functioning of many ecosystems (Gessaman and MacMahon, 1984; Huntly, 1991; Hobbs, 1996; Naiman and Rogers, 1997). In riparian

* Correspondence to: Stewart W. Breck, National Wildlife Research Center, 4101 LaPorte Ave., Fort Collins, CO 80521, USA.

E-mail: stewart.w.breck@aphis.usda.gov

This article is a US Government work and 
ecosystems, beavers can be important because of their ability to cut down trees and remove an exceptionally large amount of biomass (Gill, 1971; Johnston and Naiman, 1990). In some instances, these abilities allow beavers to suppress tree populations (Barnes and Dibble, 1988; Johnston and Naiman, 1990; Nolet et al., 1994). Whether or not a particular tree species is affected by beavers will depend on a number of factors, including the abundances of both trees and beavers as well as factors that influence foraging rates (McGinley and Whitham, 1985; Johnston and Naiman, 1990; Morgan et al., 1997; Augustine and McNaughton, 1998).

Our understanding of the circumstances that result in beavers affecting tree populations varies among the habitats these herbivores occupy. Research on beaver foraging has been conducted primarily where beavers create ponds or in artificial settings that simulate beaver ponds. On large rivers, where beavers cannot create ponds, less is known about their foraging behaviour or how the dynamics of river flow might affect it. Where cottonwood recruitment is abundant, beaver herbivory is likely to impact the growth and survival of trees close to the river (McGinley and Whitham, 1985), though it appears to play a minor role in limiting or regulating the cottonwood population (Strong, 1982; Andersen and Cooper, 2000). On flow-regulated rivers, cottonwood recruitment can be spatially restricted (Cooper et al., 1999; Merritt and Cooper, 2000) and that in turn could lead to a situation where trees are more vulnerable to beaver herbivory.

In this study we asked whether flow regulation and the subsequent changes in cottonwood density have altered the foraging behaviour of beavers and/or their influence on cottonwood tree populations. To address these questions we compared beaver cutting rates and the associated risk to individual cottonwood saplings on two rivers: the free-flowing Yampa River and the flow-regulated Green River. We report on factors found to be important in the interaction, including cottonwood tree densities, spatial arrangement of cottonwood patches, the magnitude and duration of floods (including a controlled flood) and the presence of alternative forage. Our work extends that of Andersen and Cooper (2000) who studied the effect of all mammalian herbivores on the survival of cottonwood seedlings on the Yampa and Green Rivers. We assessed conditions at a Green River site more regulated than the site examined by those authors, focused strictly on beaver herbivory, and measured herbivory during the first relatively large, controlled flood on the Green River since 1986.

\section{Study reaches}

We conducted our study on the Green and Yampa rivers in northwestern Colorado. Our study sites were in alluvial valleys: Browns Park on the Green River and Deerlodge Park on the Yampa River (Figure 1). The Yampa River is free flowing, whereas the Green River has had its flow regulated since the 1962 completion of Flaming Gorge Dam. Both rivers are tributaries of the Colorado River with headwaters in the Rocky Mountains. In the areas studied, both rivers are sixth order and feature fine-textured beds.

The main assumption of our study was the prior to completion of Flaming Gorge Dam, the Green and Yampa rivers featured similar flow regimes and maintained similar riparian ecosystems. Flow data show the similarity in the historical flow regime and pre-dam aerial photos demonstrate the similarity of the ecosystems, which consisted primarily of Fremont cottonwood (Populus deltoides subsp. wislizenii) and sandbar willow (Salix exigua). Details of the historic flow regimes and support for our assumption are in Andrews (1986), Cooper et al. (1999), Andersen and Cooper (2000), and Merritt and Cooper (2000).

On the Yampa River, recruitment of cottonwood trees occurs primarily on unvegetated, vertically accreting bars, typically opposite cutbanks and often far from the base flow channel position (Cooper et al., 1999). Seedlings are typically found in lower elevation stands, saplings at intermediate elevations and mature individuals at higher elevations on the floodplain (Merritt and Cooper, 2000). During exceptionally large (and hence rare) spring floods (e.g. 1984), seedlings can also become established via overbank flooding on fresh alluvium deposited on the high floodplain adjacent to cutbanks (Scott et al., 1997). On the Green River in Browns Park, flow regulation has led to the formation of mid-channel islands and the elimination of point bars (Cooper et al., 1999; Merritt and Cooper, 2000). As a result, recruitment of Fremont cottonwood has severely declined and sandbar willow has shifted from a primarily bank-oriented species to a primarily island-oriented species (Cooper et al., 1999; Merritt and Cooper, 2000). 


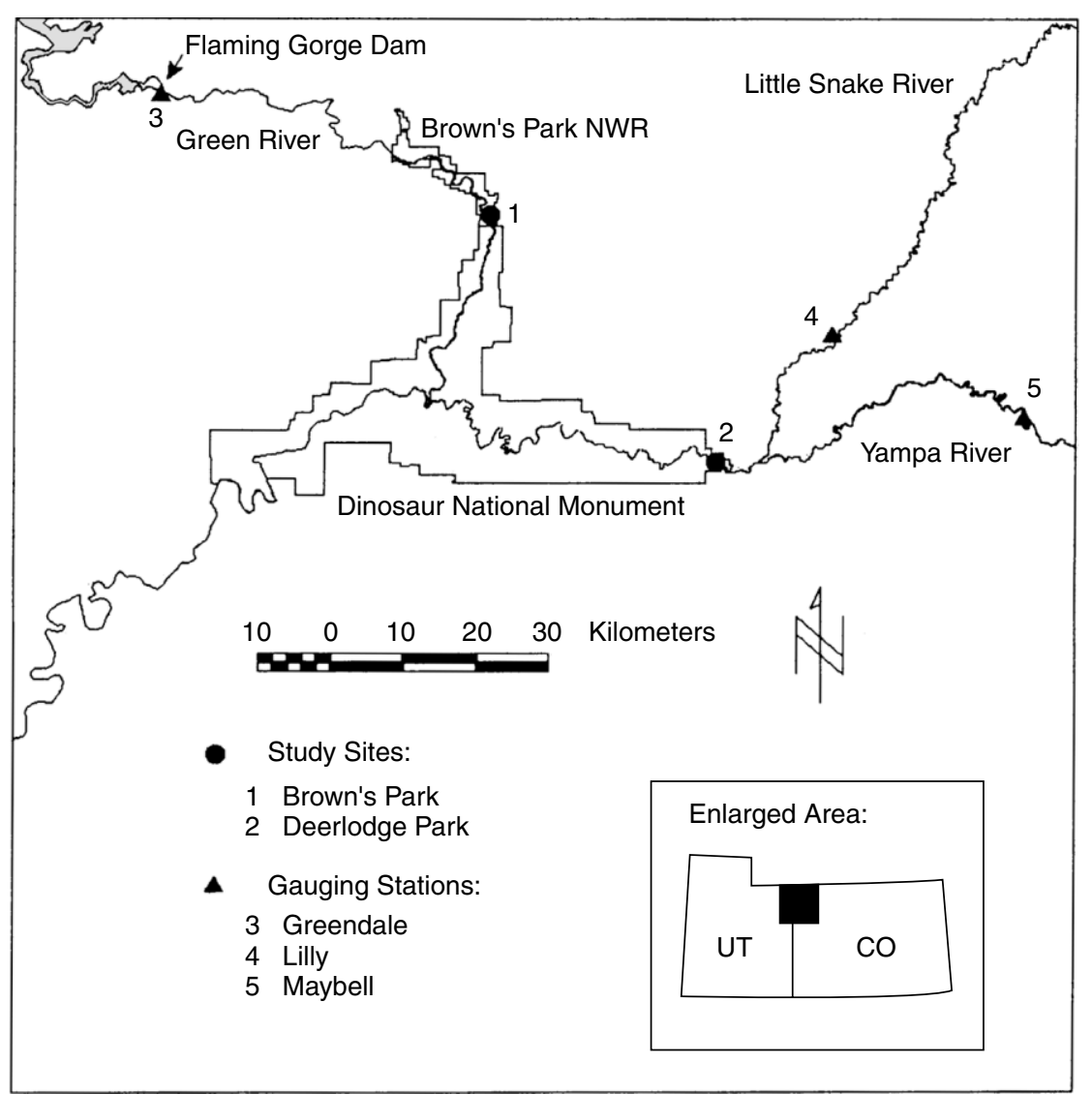

Figure 1. Location of Browns Park and Deerlodge Park study areas on the Green and Yampa Rivers, respectively. The locations of USGS gauging stations whose records were used for determining flow magnitude through the study areas are also shown. Flaming Gorge Dam is near the Greendale gauging station

\section{METHODS}

\section{Flow rates}

We obtained flow data for the period 1 September 1997 to 1 November 1999 from USGS gauging stations (Figure 1). For Browns Park, we used data from the Greendale, UT gauge (09234500) located just below the dam. For Deer Lodge Park, we summed discharges of the Yampa River at Maybell, CO (gauge 09251000) and the Little Snake River at Lily Park, CO (gauge 09260000). We assessed water depth in one cottonwood patch (GU5, described below) on the Green River during the controlled flood in 1999 and the same period in 1998.

\section{Cottonwood abundance}

We estimated the abundance of cottonwood saplings less than $100 \mathrm{~mm}$ diameter at $30 \mathrm{~cm}$ above ground on each river by quantifying the total area of cottonwood patches, and the density of saplings within them. We created ArcView GIS coverages of patches containing sapling cottonwood in each study area using aerial photos taken in July 1997 and August 1995 on the Green and Yampa Rivers, respectively. Each reach was also carefully examined by means of walking and canoeing, and the photography-based GIS patch boundaries modified to reflect conditions found on the ground. On the Yampa River, each patch was classified as associated with a cutbank or with vertically accreting bars. On the Green River both sides of the river form cutbanks due to ongoing channel widening (Merritt and Cooper, 2000), making classification unnecessary. 
We used ArcView software to estimate the total area of cottonwood on each river. To develop a comparable estimate between rivers, we divided number of patches and total area of patches by the length of the study reach, measured on the mid-point of the active channel on each river. The lengths of the study reaches (10.1 and $8.6 \mathrm{~km}$ on the Green and Yampa rivers, respectively) were calculated based on radio telemetry data of beavers living within the reaches (i.e. the maximum range over which tracked animals travelled; Breck et al., 2001). Our estimates of cottonwood tree density were based on data from belt transects, described below.

\section{Belt transects}

In May 1998, we established sets of belt transects perpendicular to the river in three cottonwood patches on the Yampa River (YDE, YCM, and YCB) and two patches on the Green River (GAB and GU5). Our goal was to place transects in three patches on each river but our Green River study area contained only the two patches sampled. Further, because of the lower density of saplings on the Green River we used $2 \mathrm{~m}$ wide transects, whereas the Yampa transects were $1 \mathrm{~m}$ wide. On the Yampa River, we placed transects only in patches of cottonwood saplings associated with accreting bars because patches associated with cutbanks were both uncommon and relatively small in extent, and we considered them unlikely to contribute significantly to gallery forest dynamics.

We determined the number and position of transects by first calculating parallel-to-the-river length of each patch and dividing this length by 10; this determined the distance between transects. A random starting point for the first transect was chosen within the first $25 \mathrm{~m}$ of the upstream end of the cottonwood patch. Parallelto-the-river length ranged from 300 to $470 \mathrm{~m}$ on the Green River and from 150 to $900 \mathrm{~m}$ on the Yampa River. This process resulted in patches containing nine or ten transects, with the exception of one small patch on the Yampa River (YCB) that had four transects. We estimated the mean density of cottonwood saplings on each river by calculating the density within each belt transect (number of saplings/transect area), and then averaging the transect densities for each river.

All saplings in each transect were tagged and the diameter at $30 \mathrm{~cm}$ above ground recorded. Saplings with a diameter less than $7 \mathrm{~mm}$ were ignored, because observations indicated that beavers did not cut below this diameter (S. Breck, personal observation). From May 1998 to November 1999 we assessed the condition of each tagged tree a total of eight times (i.e. encounter occasion) on the Yampa River and nine times on the Green River (Figure 2), including the initial marking occasion. We added an interval on the Green River (interval 6b, Figure 2) to isolate the effect of the peak flow during a large, controlled flood in 1999. The intervals between encounter occasions varied in length from one to four months. At each encounter occasion, we classified each tree as alive and uncut, cut by beaver, dead and not cut by beaver, or not found.

\section{Distance from river}

We measured the distance between the river's edge and every tree tagged in the belt transects. On the Yampa River the distance from a tree to the river varied dramatically throughout a year because of large changes in stage and a typically gentle slope between the thalweg and the patches sampled. Because distance varied, we generated two measurements hereafter termed flood flow distance and base flow distance. Flood flow distances of trees on the Yampa River were generated by assigning a distance of $0 \mathrm{~m}$ for the sapling in each transect that was closest to the river. Flood flow distances for the remaining trees in each transect were then measured relative to that first tree. Base flow distance was calculated as the flood flow distance plus the distance from the end of each belt transect to water under the 1995 base flow conditions represented in the GIS. On the Green River, where banks are essentially vertical and stage change small, the base flow distance from the river to trees was measured from the edge of the bank to each tree. This distance stayed constant except for one month during the controlled flood in 1999. During this flood period all trees were assigned a distance value of $0 \mathrm{~m}$ because the flood inundated the patches to nearly the same depth.

\section{Cutting rate}

We estimated the total number of saplings cut per beaver colony on each study reach by first dividing the number of transect saplings classified as cut by the proportion of total area of cottonwood included within 


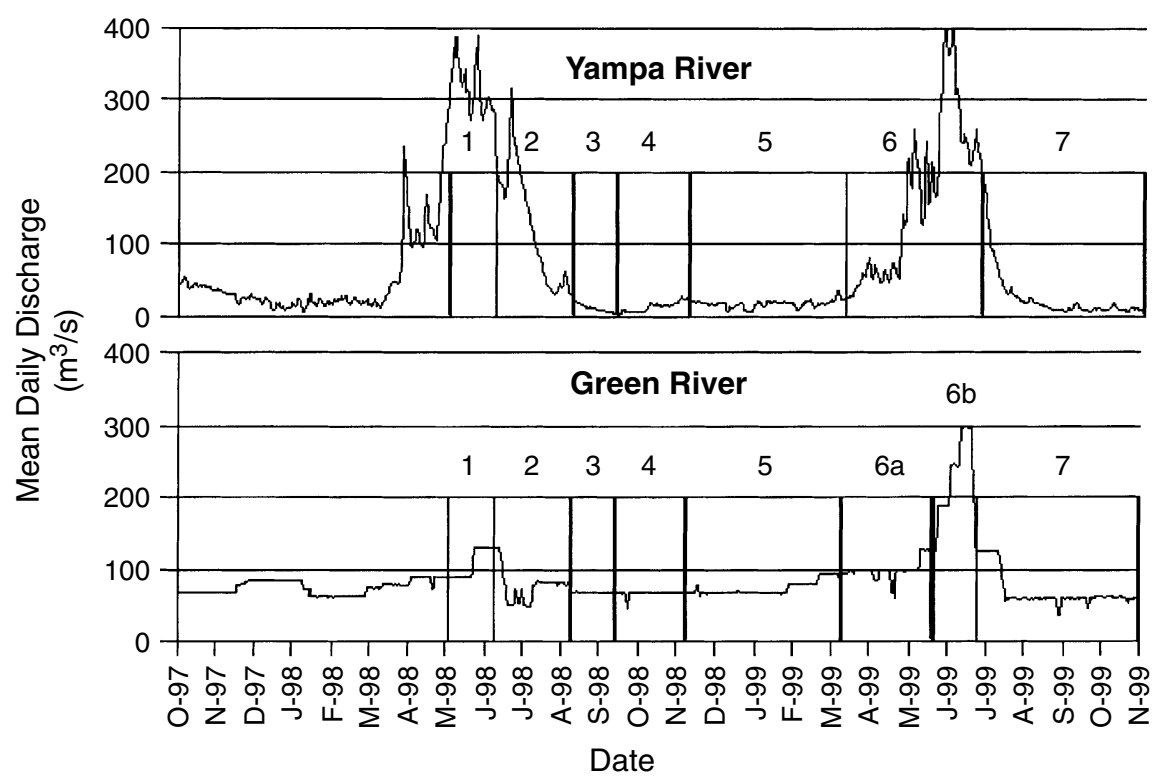

Figure 2. Daily mean discharge for the period October 1997 to November 1999 for the Yampa River in Deerlodge Park and the Green River in Browns Park in northwest Colorado. The vertical bars represent encounter occasions when marked cottonwood trees were checked and classified as to condition. The periods between bars are intervals for which we calculated probabilities of saplings escaping herbivory. There were seven intervals on the Yampa River and eight on the Green River

the transects (i.e. estimated total number of cut saplings $=$ number of cut saplings in transects/proportion of cottonwood area sampled by transects). Cutting rate was estimated by dividing the above result by the number of beaver colonies censused on each river section (i.e. cutting rate $=$ estimated total number of cut saplings/number of beaver colonies). The number of beaver colonies in each study section was determined annually for three years through visual surveys, trapping, and radio telemetry as part of an effort to determine the demographic response of beavers to flow regulation (see Breck et al. (2001) for details). We used colonies instead of individual animals for our calculation because the number of colonies could be determined unambiguously and it stayed constant on each river throughout the study, whereas the number of individuals was a statistical estimate with an associated degree of uncertainty. Our assumption was that the average number of beavers per colony was the same on each river. This assumption was reasonably supported through our trapping data, in which we found an adult pair, one or two subadults and several juveniles at every den on both rivers.

\section{Analyses}

We used likelihood-based methods (Buckland et al., 1997; Burnham and Anderson, 1998) to quantify strength of evidence for alternative models explaining patterns of cottonwood herbivory between rivers. The approach has been formalized in techniques for selecting among competing models of ecological phenomena (Buckland et al., 1997; Hilborn and Mangel, 1997; Burnham and Anderson, 1998). Although these statistical approaches are described in detail by Burnham and Anderson (1998), they are probably unfamiliar to many ecologists, so we offer a brief overview here.

The shared goal of these techniques is to assess the relative strength of evidence supporting the candidate models. The relative support for models in data can be assessed using likelihood theory combined with Akaike's information criterion (AIC; Akaike, 1973). A single AIC value has no interpretation by itself, but comparing AIC values among alternatives allows us to assess the relative support in the data for two or more models. AIC puts a penalty on model complexity (through the number of parameters) so that an optimum is reached between model accuracy and parsimony. 
We are interested in the relative support in the data for alternative models. We assess that support using the difference between AIC values:

$$
\Delta_{r}=A I C_{r}-\min (A I C)
$$

where $\min (A I C)$ is the model with the minimum AIC value. This model corresponds to the single best model selected from the alternatives given the data at hand. The $\Delta_{r}$ are proportional to differences in Kullback-Leibler distances and thus provide a rigorous way to assess the difference in the information provided by alternative models. The $\Delta_{\mathrm{r}}$ can be interpreted as follows (Burnham and Anderson, 1998). Models with $\Delta_{r} \leq 2$ have support in the data rivalling the best model and should be considered carefully in making inferences about the modelled processes. Models with $3<\Delta_{r} \leq 7$ have substantially less support, but remain candidates. Models with $\Delta_{r}>10$ have essentially no support in the data relative to the model with the smallest AIC. Estimating the 'weight' or likelihood of each model is another means for reporting the relative support for alternative models, where the sum of all the weights from a candidate list of models sums to 1 . Thus a model with a weight of 1 has complete support and a model with a weight of 0 has no support. We used the small-sample correction of AIC adjusted for overdispersion $\left(\right.$ QAIC $_{\mathrm{c}}$; see Lebreton et al., 1992; Burnham and Anderson, 1998, p. 53) and we reported both $\Delta_{\mathrm{r}}$ and weight.

We used the known fates option in program MARK (White and Burnham, 1999) to perform the analyses. Known fates is a model based on capture-recapture methodology where individuals are marked and then followed through time. Each 'recapture' occasion enabled us to estimate the probability of a sapling escaping herbivory (PSEH) for that interval. Marked saplings are ideal for the known fates model because there is a high probability of finding all marked individuals on each search occasion. Those saplings that died or could not be found were censored from the data set at the beginning of the interval when they were recorded as dead or lost. Censuring prevents the individual from continuing to contribute to the analysis from that point.

We first compared the PSEH on the Green River versus the Yampa River. For this analysis we eliminated the extra encounter occasion (at the end of interval 6a, Figure 2) from the Green River so that intervals were equal between rivers. We hypothesized the following models:

$[S()]-.P S E H$ was the same for all five patches and all time intervals;

[S(r)] - PSEH differed between rivers;

[S(p)]-PSEH differed for all five patches;

[S(t: all)]-PSEH differed for each time interval;

[S(t: flood)]-PSEH was higher during the flood intervals $(1,2$, and 6$)$;

$[\mathrm{S}(\mathrm{t}$ : fall $)]$ - PSEH was higher during the autumn intervals $(3,4$, and 7$)$;

$[\mathrm{S}(\mathrm{r}+\mathrm{t}: \mathrm{all})]-\mathrm{PSEH}$ differed between rivers and differed for each time interval;

$[\mathrm{S}(\mathrm{p}+\mathrm{t}: \mathrm{all})]$ - PSEH differed for all five patches and for each time interval;

$[\mathrm{S}(\mathrm{r}+\mathrm{t}$ : flood $)]-\mathrm{PSEH}$ differed between rivers and was higher during flood intervals $(1,2$, and 6$)$;

$[\mathrm{S}(\mathrm{p}+\mathrm{t}$ : flood $)]-\mathrm{PSEH}$ differed for all five patches and was higher during flood intervals $(1,2$ and 6$)$;

$[\mathrm{S}(\mathrm{p}+\mathrm{t}$ : fall, flood $)]$ - PSEH differed for all five patches and was higher for autumn intervals $(3,4$, and 7 ) and flood intervals $(1,2$, and 6) and differed between autumn and flood periods.

We performed the analysis with the above models and then tested whether two covariates (base flow distance and stem diameter) would improve our models by adding each covariate, separately, to the top three models from the above analysis. Models with these covariates tested whether distance from water or size of sapling influenced a tree's likelihood of being cut by beavers (Jenkins, 1980). Because base flow distance measurements were confounded by flood intervals and probably interfered with our ability to detect distance and size relations in food selection, we performed an additional analysis using the Kolmogorov-Smirnov two-sample test (Sokal and Rohlf, 1981). We tested for differences in cumulative frequency distributions (CFD) between cut saplings and available saplings for both variables (distance and diameter) during flood and base flow periods on both rivers. 
For the second analysis, we focused on the Green River to isolate how controlled flooding affected probabilities of saplings escaping herbivory by beaver. There were two patches (GU5 and GAB) and eight time intervals. We hypothesized the following models a priori to analysis:

$[S()]-.P S E H$ was the same for both patches and all time intervals;

[S(t: all)]-PSEH differed for each time interval;

$[\mathrm{S}(\mathrm{p})]-\mathrm{PSEH}$ differed between both patches;

$[\mathrm{S}(\mathrm{p}+\mathrm{t}:$ all $)]-\mathrm{PSEH}$ differed for both patches and each time interval;

$[S(p+t:$ flood $)]-P S E H$ differed for both patches and was higher during the controlled flood (interval $6 b)$;

$[\mathrm{S}(\mathrm{p}+\mathrm{t}$ : spring 1$)]-\mathrm{PSEH}$ differed for both patches and was the same and higher during the two spring time intervals (1 and 6b);

$[S(p+t$ : spring2)]-PSEH differed for patches, and differed between the first spring interval (1), the second spring interval (6b), and all other time intervals.

\section{RESULTS}

\section{Flow rates}

The peak discharge of the Yampa River during the 1999 spring flood was slightly larger than the peak in 1998, and both years featured peak flows slightly above the long-term average $\left(381 \mathrm{~m}^{3} \mathrm{~s}^{-1}\right)$ (Figure 2). The period of generally high flow $\left(\geq 250 \mathrm{~m}^{3} \mathrm{~s}^{-1}\right)$ lasted for about five weeks in 1998, whereas it lasted about three weeks in 1999. The peak flow of the Green River during 1998 was about $130 \mathrm{~m}^{3} \mathrm{~s}^{-1}$, whereas a peak of $300 \mathrm{~m}^{3} \mathrm{~s}^{-1}$ was sustained for about one week during the controlled flood of 1999, and discharge $\geq 200 \mathrm{~m}^{3} \mathrm{~s}^{-1}$ was sustained for about four weeks (Figure 2). In late spring 1998 (interval 1, Figure 2) only a small portion of the patch (GU5) on the Green River was inundated to a depth of approximately $0.5 \mathrm{~m}$; the remainder of the patch had no standing water. The 1999 flood (interval 6b, Figure 2) inundated all of GU5 to a depth of $0.5-1.0 \mathrm{~m}$ for 30 days.

\section{Cottonwood characteristics}

The base flow distances of cottonwood patches $(\bar{x} \pm \mathrm{SE})$ from the river were 1.5 to 4 times less on the Green River (GAB: $59 \pm 1.74 \mathrm{~m}$; GU5: $42 \pm 1.29 \mathrm{~m}$ ) than they were on the Yampa River (YDE: $175 \pm 2.50 \mathrm{~m}$; YCM: $160 \pm 2.13 \mathrm{~m}$; YCB: $86 \pm 1.54)$. The average diameter of saplings $(\bar{x} \pm \mathrm{SE})$ was smaller on the Green River (GAB: $28.5 \pm 2.92 \mathrm{~mm}$; GU5: $17.4 \pm 0.76 \mathrm{~mm}$ ) than on the Yampa River (YDE: $36.5 \pm 1.63 \mathrm{~mm}$; YCM: $25.3 \pm 0.64 \mathrm{~mm}$; YCB: $29.7 \pm 1.59 \mathrm{~mm})$. Cottonwood area/km, number of patches $/ \mathrm{km}$ and density (saplings $/ \mathrm{m}^{2}$ ) were much lower on the Green River compared to the Yampa River (Table I). On the Yampa River approximately $64 \%$ of the area containing cottonwood saplings was located on vertically accreting bars and the remainder was on high flood plains adjacent to cutbanks (Table I).

Table I. Characteristics of patches of young cottonwood in the study reaches on the Green and Yampa Rivers in northwest Colorado, 1999

\begin{tabular}{|c|c|c|c|c|c|c|}
\hline \multirow[t]{2}{*}{ River $^{\mathrm{a}}$} & \multicolumn{2}{|c|}{$\begin{array}{c}\text { Patch } \\
\text { area }\left(\mathrm{m}^{2}\right)\end{array}$} & \multicolumn{2}{|c|}{$\begin{array}{l}\text { Number of } \\
\text { patches }\end{array}$} & \multicolumn{2}{|c|}{$\begin{array}{l}\text { Cottonwood stem density } \\
\quad\left(\text { saplings per } \mathrm{m}^{2}\right)\end{array}$} \\
\hline & Total & per km & Total & per $\mathrm{km}$ & Mean & SE \\
\hline Green & 20336 & 2707 & 2 & 0.30 & 0.22 & 0.04 \\
\hline Yampa (total) & 87992 & 10232 & 17 & 1.98 & unknown & unknown \\
\hline Yampa (VAS) & 56454 & 6564 & 6 & 0.70 & 1.01 & 0.17 \\
\hline
\end{tabular}

a The lengths of the study reaches were 10.1 and $8.6 \mathrm{~km}$ for the Green and Yampa rivers, respectively. Total = all areas with saplings; VAS = cottonwood saplings within areas of vertically accreting bars. 
Table II. Top four of 17 candidate models (selected using AIC model selection procedure, see Methods) comparing probability of cottonwood saplings escaping herbivory by beaver on the Green and Yampa Rivers

\begin{tabular}{lcccrc}
\hline Model & QAIC $_{c}$ & $\Delta$ QAIC $_{c}$ & Weight & NPAR & Deviance \\
\hline$[\mathrm{S}(\mathrm{p}+\mathrm{t})]$ & 1503.49 & 0.00 & 0.423 & 11 & 1674.1 \\
{$[\mathrm{~S}(\mathrm{p}+\mathrm{t})+$ diam $]$} & 1503.66 & 0.18 & 0.387 & 12 & 1671.9 \\
{$[\mathrm{~S}(\mathrm{p}+\mathrm{t})+$ dist $]$} & 1505.08 & 1.59 & 0.191 & 12 & 1673.6 \\
{$[\mathrm{~S}(\mathrm{p}+\mathrm{t}:$ fall,flood $)]$} & 1532.33 & 28.85 & 0.000 & 8 & 1713.5 \\
\hline
\end{tabular}

QAIC $_{c}$ is a version of Akaike's information criteria adjusted for overdispersion; $\triangle \mathrm{QAIC}_{\mathrm{c}}$ is QAIC differences relative to the smallest QAIC value in the set; Weight is an estimate of the likelihood of each model; NPAR is the number of parameters in a model. Variables in models are: p, five patches (three on the Yampa River and two on the Green River); $t$, seven time intervals (see Figure 2); diam and dist are covariates that represent the diameter of each tree and the distance of each tree from the river, respectively.

\section{Cutting rate}

Beavers cut 199 of 561 marked saplings on the Green River and 42 of 934 marked saplings on the Yampa River during the 17-month study. We sampled $12.5 \%$ of the total area of young cottonwood patches on the Green River and $2.0 \%$ of young cottonwood patches associated with vertically accreting bars on the Yampa River. Over three years (1997-2000) the number of beaver colonies on each river section stayed constant at five on the Green River and three on the Yampa River (Breck et al., 2001). The estimated cutting rate (number of saplings cut/beaver colony) for the 17-month interval was three times lower on the Green River (318 saplings cut/beaver colony) than for the cottonwood patches on the Yampa River (1076 saplings cut/beaver colony).

\section{PSEH: Yampa versus Green River}

Model $[\mathrm{S}(\mathrm{p}+\mathrm{t})]$ was the top model (weight $=0.423$, Table II), indicating that the probabilities of a sapling escaping herbivory were different in each of the five patches and for each of the seven time intervals (Figure 3). PSEH were less during intervals 1, 6 and 7 for both patches on the Green River and patch YCB on the Yampa River (Figure 3). Over the 17-month long study period saplings in patches on the Green River had a lower PSEH $(p \pm \mathrm{SE})(\mathrm{GU} 5=0.66 \pm 0.028$ and $\mathrm{GAB}=0.88 \pm 0.011)$ than saplings in patches on the Yampa River ( $\mathrm{YDE}=0.99 \pm 0.003, \mathrm{YCM}=0.99 \pm 0.003, \mathrm{YCB}=0.95 \pm 0.008)$. Patches nearest the river (based on base flow distances, i.e. GU5 on the Green River and YCB on the Yampa River) had the lowest PSEH on both rivers.

\section{Distance and size}

Adding the covariates distance and diameter to the model $[\mathrm{S}(\mathrm{p}+\mathrm{t})]$ did not greatly improve the performance of the model (Table II), indicating weak evidence that beavers selected saplings based on their distance from water and diameter. Both covariate values were negative (distance $=-1.243$, diameter $=-0.477$ ) indicating that beavers were selecting saplings closer to the river and smaller saplings. The Kolmogorov-Smirnov tests indicated that there was a strong difference between CFDs for the variable distance during base flows on the Green River (flood flows: $k s=1.169, p=0.130$; base flows: $k s=1.47, p=0.027$ ) (Figure 4) and during both periods on the Yampa River (flood flow: $k s=2.439, p<0.001$; base flow: $k s=1.91, p=0.001$ ) (Figure 5). The variable diameter showed little difference between CFDs on the Green (flood flow: $k s=$ $1.315, p=0.063$; base flow: $k s=0.794, p=0.567$ ) (Figure 4) and Yampa (flood flow: $k s=1.078, p=$ 0.196; base flow: $k s=0.424, p=0.999$ ) rivers (Figure 5).

\section{PSEH: controlled flood on the Green River}

The model $[\mathrm{S}(\mathrm{p}+\mathrm{t})]$ was the top model (weight $=1$, Table III), indicating that the probability of a sapling escaping herbivory by beaver differed between the two patches and eight time intervals on the Green River 


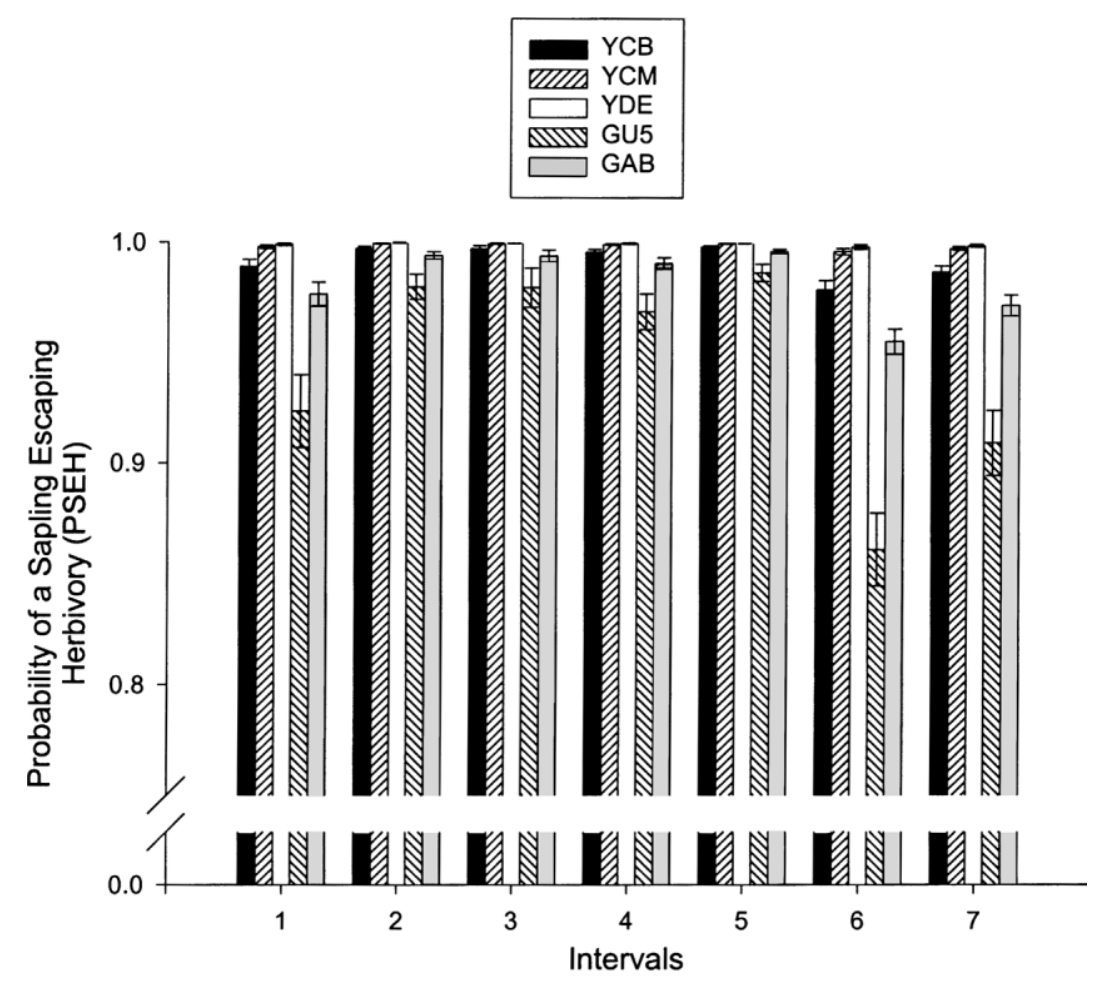

Figure 3. Probability of a cottonwood sapling escaping herbivory by beaver ( \pm 1 SE) for the seven time intervals (Figure 2$)$ in three patches on the Yampa River (YCB, YCM, YDE) and two patches on the Green River (GU5 and GAB). Interval 6 for patches on the Green River is a combination of intervals $6 a$ and $6 b$ (Figure 2). Probability estimates for each patch and each time interval were taken from the model $[\mathrm{S}(\mathrm{p}+\mathrm{t})]$, the most parsimonious model in the AIC model selection procedure (Table II)

(Figure 6). The mean PSEH ( $p \pm$ SE) during non-flood periods (i.e. mean of all intervals except $6 \mathrm{~b}$ ) was $0.959 \pm 0.011$ for GU5 and $0.985 \pm 0.003$ for GAB. Interval $6 \mathrm{~b}$ (1999 controlled flood interval) had the lowest PSEH $(p \pm$ SE) for both patches $(\mathrm{GU} 5=0.699 \pm 0.034 ; \mathrm{GAB}=0.889 \pm 0.015)$. In all intervals, the PSEH was lower in patch GU5 than in GAB (Figure 6).

\section{Hypothetical cutting rates in the absence of flooding}

On the Green River, beavers cut 20 saplings during the 30-day period in early summer 1998 (interval 1, Figure 2) and over three times more (64 saplings) during the 30-day flood period in early summer 1999 (interval 6b, Figure 2). Recalculating the cutting rate for the 17-month period, assuming that beaver would

Table III. Top four of seven candidate models (selected using AIC model selection procedure, see Methods) comparing probabilities of cottonwood saplings escaping herbivory by beaver in two patches on the Green River

\begin{tabular}{lccccc}
\hline Model & QAIC $_{c}$ & $\Delta$ QAIC $_{c}$ & Weight & NPAR & Deviance \\
\hline$[\mathrm{S}(\mathrm{p}+\mathrm{t})]$ & 564.34 & 0.00 & 1.000 & 9 & 1332.9 \\
{$[\mathrm{~S}(\mathrm{t})]$} & 589.10 & 24.77 & 0.000 & 8 & 1398.3 \\
{$[\mathrm{~S}(\mathrm{p}+\mathrm{t}:$ spring2) $]$} & 593.42 & 29.08 & 0.000 & 4 & 1428.4 \\
{$[\mathrm{~S}(\mathrm{p}+\mathrm{t}:$ spring 1$)]$} & 609.57 & 45.23 & 0.000 & 3 & 1472.7 \\
\hline
\end{tabular}

$\mathrm{QAIC}_{\mathrm{c}}$ is a version of Akaike's information criteria adjusted for overdispersion; $\triangle \mathrm{QAIC} \mathrm{c}_{\mathrm{c}}$ is QAIC differences relative to the smallest QAIC value in the set; Weight is an estimate of the likelihood of each model; NPAR is the number of parameters in a model. Variables in models are: p, two patches (Gu5 and GAB); t eight time intervals (see Figure 2). 

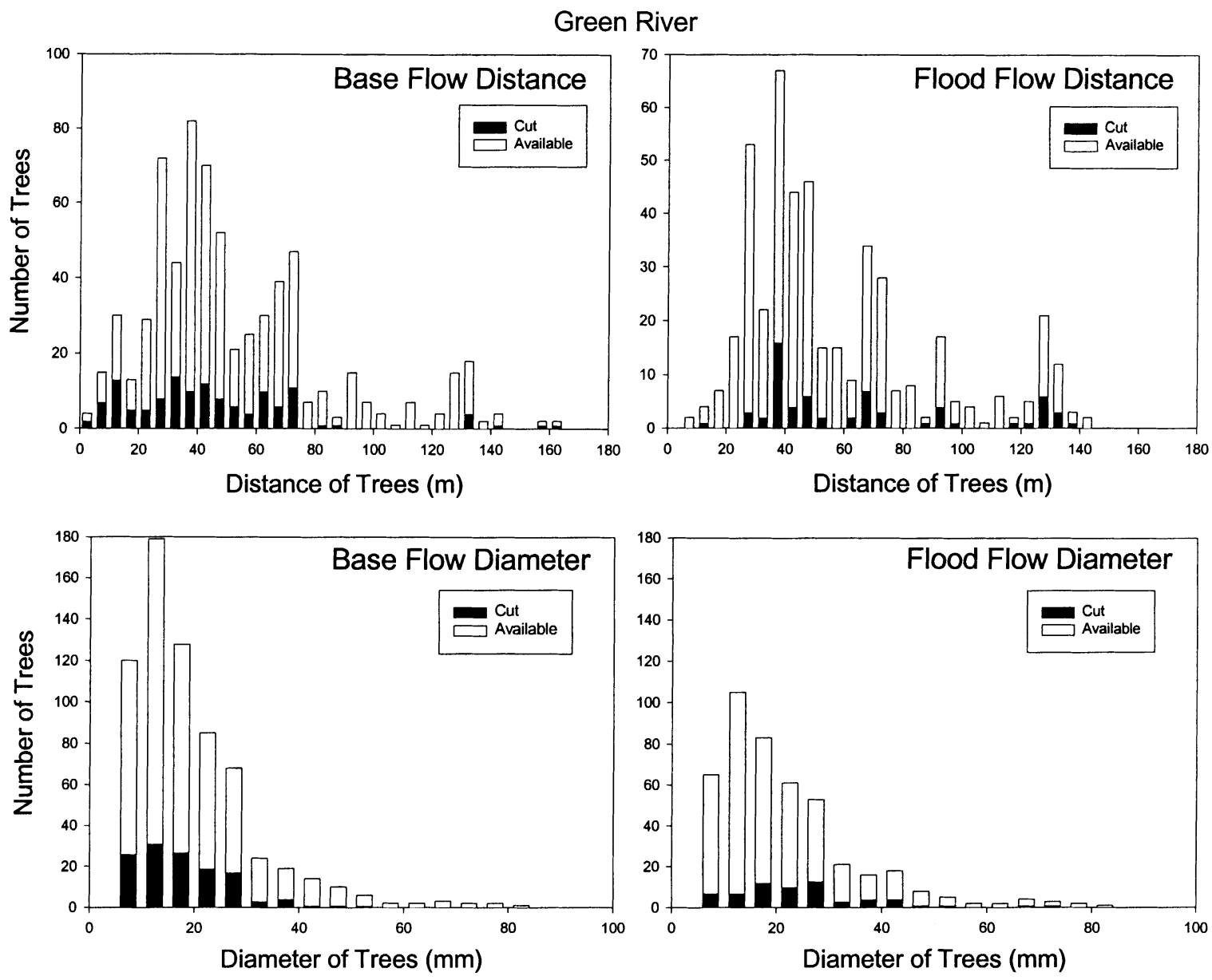

Figure 4. Frequency distribution of available and beaver-cut cottonwood trees in relation to their diameter (mm) and distance from water (m) during base flow and flood flow periods on the Green River in northwest Colorado, May 1998 to November 1999

have cut 20 saplings in the absence of a controlled flood during the same period in 1999, results in a total of 155 saplings cut and a cutting rate of 248 cut/beaver colony ( $22 \%$ lower than the original cutting rate). On the Yampa River beavers cut 13 saplings during the ten months (1.3 saplings/month) of low water (intervals 3, 4, 5, and 7; Figure 2) and 29 saplings during the seven months (4.1 saplings/month) of high water (intervals 1 , 2, and 6; Figure 2). Recalculating the cutting rate for the 17-month period, assuming that beaver would have cut 1.3 saplings/month in the absence of flooding (total of seven months), results in a total of 22 saplings cut and a cutting rate of 367 cut/beaver colony ( $48 \%$ lower than the original cutting rate).

\section{DISCUSSION}

Our results are consistent with experimental work that found the probability of a tree being cut down by beavers is sensitive to the density of trees, spatial distribution and size of trees, and presence of alternative forage species (Jenkins, 1980; Fryxell, 1992, 1999; Doucet and Fryxell, 1993). Unique to this study was the demonstration that flooding can increase the probability of cottonwood saplings being cut down by beavers by decreasing the distance of trees from water. Furthermore, our results demonstrate that beavers affected a large proportion of cottonwood on the Green River (25\% per year), which we suggest was primarily due to the low density of cottonwood, the trees' closer proximity to water, and the maintenance of a large beaver population by alternative forage (Breck et al., 2001). 


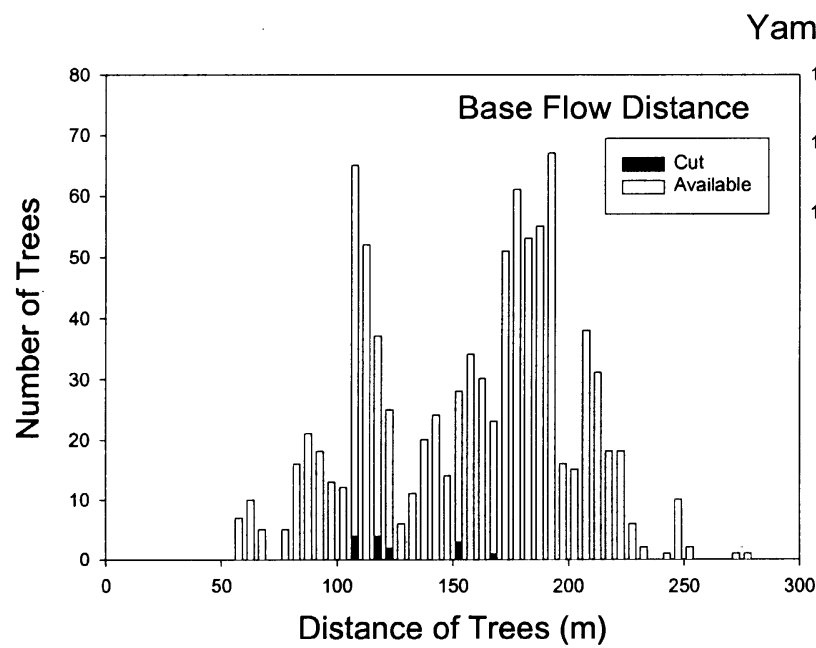

\section{Yampa River}
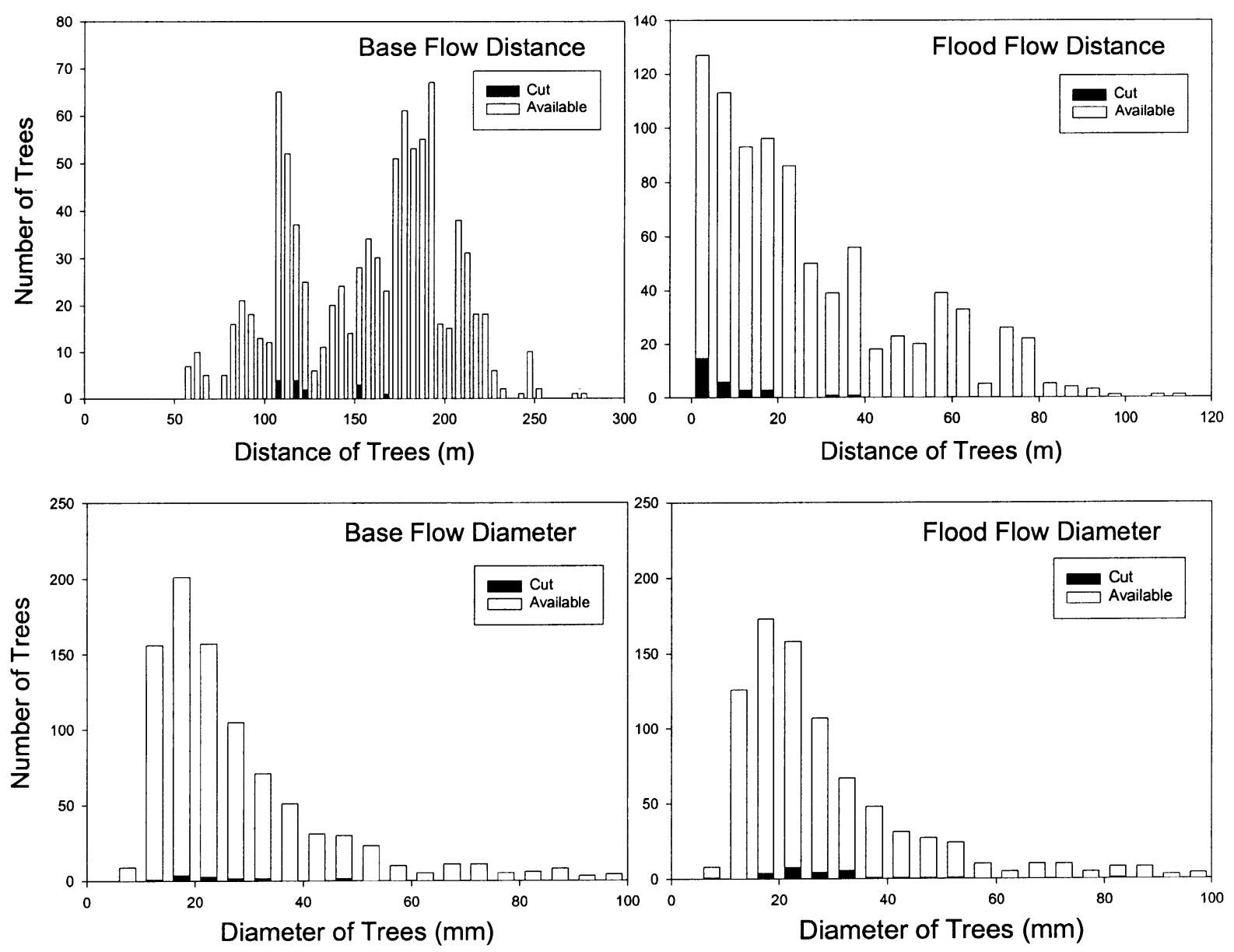

Figure 5. Frequency distribution of available and beaver-cut cottonwood trees in relation to their diameter (mm) and distance ( $\mathrm{m}$ ) from water during base flow and flood flow periods on the Yampa River in northwest Colorado, May 1998 to November 1999

\section{Cutting rate}

For the 17-month study period, the cutting rate of cottonwood saplings by beavers was over three times less on the Green River (318 saplings/beaver colony) than on the Yampa River bars (1076 saplings/beaver colony). Theory suggests that search time increases when prey density is lower, which decreases the number of prey a consumer is able to process (Holling, 1959). Our results support this theory as the Green River had a much lower within-patch density of cottonwood saplings, as well as a lower patch density, compared to the Yampa River and a lower cutting rate. However, we believe other factors, including some related to handling time, (i.e. availability of alternative forage, tree size, distance of saplings from water, and flooding) contributed to the difference in cutting rate between rivers.

Cutting rates associated with a forage species are generally dependent upon the density, availability and nutritional quality of other forage species (Fryxell and Doucet, 1993; Fryxell, 1999). On the Green River, willow has responded to flow regulation by shifting its distribution from a bank-oriented species to an islandoriented species (Merritt and Cooper, 2000; Breck, 2001). This shift has decreased distance of willow to water, which implies that energetic costs and risk of predation associated with searching and harvesting have decreased (Basey and Jenkins, 1995). Willow is a good food source for beavers (Baker and Cade, 1995), and although cottonwood may be preferred (S. Breck, personal observation), the costs associated with searching for and harvesting willow have decreased relative to the costs associated with cottonwood trees. Thus the 


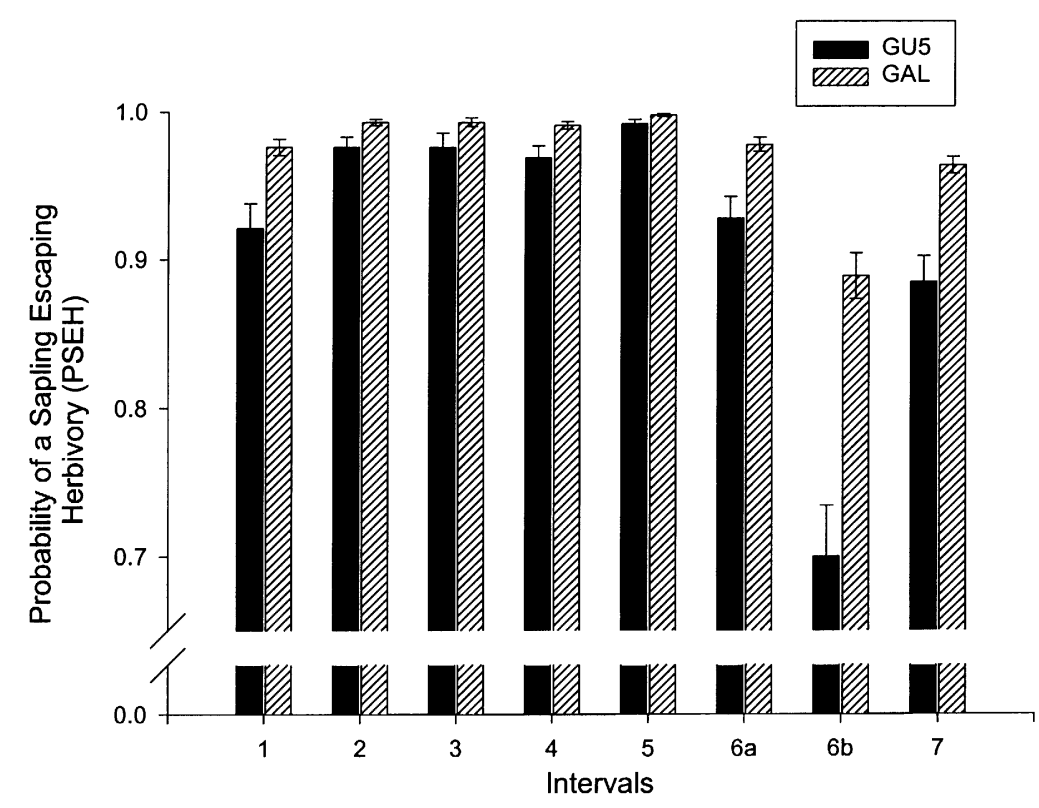

Figure 6. Probability of a cottonwood sapling escaping herbivory by beaver ( \pm 1 SE) from May 1998 to November 1999 on the Green River in northwest Colorado. Probability estimates for each patch and each time interval were taken from the model [S(p+t)], the most parsimonious model in the AIC model selection procedure (Table II). There are two groups (GU5 and GAB) and eight intervals. Interval 2 contained the peak flow of 1998 (see Figure 2), which featured a flow typical for most post-dam years, and interval 6b contained the unusually large controlled flood of 1999

cutting rate of cottonwood trees was likely also lowered by the greater availability of willow on the Green River.

Andersen and Cooper (2000) speculate that depth and duration of flooding strongly influences cutting rate by beavers. Our data support their contention. On the Green River, beavers cut three times more saplings during the one-month flood interval in 1999 than they did during a similar period in 1998. Similarly, on the Yampa River beavers cut 1.3 saplings/month during base flow periods and 4.1 saplings/month during flood flow periods. These differences in cutting rates probably resulted from floodwaters increasing access to saplings by reducing distance from water to saplings, simultaneously decreasing predation risk and the time and energy costs of foraging, and thereby allowing beavers to increase their cutting rate.

Alternatively, the higher cutting rates during flood periods could have been due to a seasonal increase in cutting in order to build up caches for autumn and winter use. We do not believe this to be the case for several reasons. First, if a seasonal effect were operating to produce the higher cutting rates on the Green River in late spring 1999, we should have observed similar cutting rates for the same period in 1998, but we did not. Second, we did not observe beavers building caches until late September, three months after the peak cutting rates we documented. Finally, it would be very difficult for beavers to store food on the Yampa River during flood periods because the higher stream power associated with floodwaters would likely wash away material cached near the winter low flow channel, and material cached elsewhere would be exposed as water levels dropped.

The fact that beavers did not increase cottonwood cutting rates during autumn periods was due primarily to the presence of alternative woody forage. On the Green River, beavers relied primarily on willow for woody forage during autumn and winter. Breck (2001) documented beavers harvesting three to five times more willow in the autumn and winter months than in spring and summer months. On the Yampa River, beavers also cut more willow during the autumn in preparation for winter (Breck, 2001), but it was likely that they also cut cottonwood from areas that we did not sample, primarily saplings in patches adjacent to cutbanks. Cutting rates of willow during autumn months were highly dependent on the position of the base flow channel relative to the woody forage. Where the base flow channel ran adjacent to willow, cutting 
rates were high, and where the base flow channel was distant from willow, cutting rates were low (Breck, 2001).

The same patterns were probably true for cottonwood saplings on the Yampa River. However, we placed transects only in patches of cottonwood associated with vertically accreting bars and during the two autumn seasons that we monitored these saplings, the base flow channel was never adjacent to them. The position of the base flow channel varies somewhat each year, but in general it runs close to cutbanks and away from areas supporting accreting bars. A more complete understanding of the importance of cottonwood as forage for beavers on the Yampa River and similar rivers will be gained by also examining cutting rates of cottonwood in patches adjacent to cutbanks.

\section{Distance and size}

Distance of trees from water and tree size can be important factors influencing cutting rates (Jenkins, 1980; Fryxell, 1992), though these relationships can be difficult to demonstrate in the field. We found strong evidence that beavers selected trees closer to water during base flow periods on both rivers and flood flow periods on the Yampa River, but not during the controlled flood on the Green River (Figure 5). The fact that flooding eliminated cutting patterns based on distance on the Green River but not on the Yampa River can be explained by differences in characteristics of cottonwood patches and the behaviour of floods on each river. On the Green River, cottonwood saplings were associated with old flood channels and all saplings within the patches were at a similar elevation. The controlled flood in 1999 inundated the patches to nearly the same depth, thus reducing the tree-to-water distance to zero making all cottonwood saplings equally available. On the Yampa River sampled cottonwood saplings were in larger patches, each of which featured an elevation gradient. Saplings in these patches were inundated to different depths, and some may not have been inundated at all. The result was maintenance, to some degree, of the differences in tree-to-water distances we originally measured.

The results of the Kolmogorov-Smirnov test and our modelling efforts showed little evidence that beavers selected cottonwood saplings based on their stem size (diameter; Figures 4 and 5). Stem size preferences shown by beaver are known to vary with the distance of trees from water (Jenkins, 1980), but in this river setting, variations in the base flow and changing floodwater levels, especially on the Yampa River, make it difficult to separate size effects from distance effects.

\section{Impact of beaver herbivory on cottonwood}

We detected differences in PSEH values between all five patches in our comparison of the Green and Yampa river. Our ability to detect even small differences between patches was enhanced by large sample sizes $(n=1482$ saplings). Our biological interpretation is that probability of escaping herbivory by beavers was lower for cottonwood saplings on the Green River (0.66-0.88) compared to those associated with vertically accreting bars on the Yampa River (0.95-0.99; Figure 3). This lower probability on the Green River was primarily due to a lower density of cottonwood, without any concomitant decrease in abundance of beavers. Predators are able to regulate or limit a prey population in situations where the prey population is suppressed to the point that they become sensitive to predation events (Krebs et al., 1995; Krebs, 1996). On the Green River flow regulation has caused the amount of area that contains young cottonwood and density of cottonwood within patches to decrease nearly five-fold compared to the Yampa River. In contrast, beaver populations have increased slightly on the Green River (Breck et al., 2001) because of increased presence and availability of willow (Breck, 2001). Despite a lower cutting rate on the Green River, beaver are able to have a greater impact because of the cottonwood population's increased sensitivity to each herbivory event.

The sensitivity of cottonwood saplings to beaver herbivory on the Green River is most clearly demonstrated by contrasting how probabilities of saplings escaping beaver herbivory changed with changes in the cutting rate. On the Green River, herbivory during the controlled flood in 1999 increased the overall cutting rate by approximately $22 \%$. This increase translated into a $19 \%$ reduction in mean PSEH value for Green River saplings during the flood interval $(0.79$ mean probability during the flood interval, 0.97 mean probability during non-flood intervals; Figure 6). On the Yampa River, flooding caused the cutting rate to increase by 
$48 \%$ for the duration of the study. However, the mean PSEH was reduced by only about $0.5 \%$ during flood intervals $(0.993$ mean probability during flood intervals, 0.998 mean probability during non-flood intervals; Figure 3).

\section{Linking flow regime to beaver herbivory}

The linkage between river regulation and patterns of beaver herbivory are equivocal in the literature. Bradley and Smith (1986) reported that beavers did not differentially affect survival of plains cottonwood (P. deltoides var. occidentalis Rydb.) between a flow-regulated and free-flowing portion of the Milk River. Andersen and Cooper (2000) reported the probability of saplings being cut by a beavers to be similar on the Yampa River ( 0.019 per year) and a partly flow-regulated site on the Green River $(0.043$ per year) below the confluence of the Green and Yampa Rivers. Their data were based on sets of small diameter saplings $(<10 \mathrm{~cm})$ in three or fewer locations at each site they examined. In contrast, our data, gathered over a larger area but including a similar size range, show the probability of a cottonwood sapling being cut was 0.032 per year on the Yampa River and 0.250 per year on the Green River at Browns Park. Nolet et al. (1994) reported that beavers heavily impacted tree species such as Alnus, Corylus, Fraxinus, Populus and Prunus because flow regulation decreased tree density and made individual trees more susceptible to herbivory. Similarly, Lesica and Miles (1999) reported that plains cottonwood ( $P$. deltoides Bartr.) was prevented from developing a mature canopy because the low density caused by flow regulation allowed beavers to suppress the recruitment into larger size classes.

These apparently conflicting results may be explained by the degree to which flow regulation affects populations of tree species preferred by beavers. In rivers where highly regulated flows result in very low recruitment of preferred tree species (e.g. Green River at Browns Park), beavers will be an important herbivore because of the sensitivity of the tree population to each tree removed. In rivers with variable flows, like the Yampa River and the Green River at Island Park (Andersen and Cooper, 2000), flooding produces an abundance of trees, which buffers the effect of foraging by beavers.

\section{Management implications}

Merritt and Cooper (2000) speculate that channel widening, currently occurring on the Green River, may create more area for cottonwood saplings to establish along channel margins. Our results indicate that beavers could limit cottonwood establishment in such a case, because the new recruitment areas will be close to the river and the absolute abundance of cottonwood will probably remain low. We recommend, if possible, encouraging the recruitment of cottonwood saplings in areas that are over $80 \mathrm{~m}$ from the river, a distance that appears to minimize the probability of a tree being cut (Figure 5). Doing so would enhance the probability that some trees are able to grow large and escape the threat of beaver herbivory.

Controlled flooding is proposed as a management technique for restoring riparian ecosystems on many regulated rivers (Stanford et al., 1996). Our results suggest that a threshold of discharge exists that allows beavers greater access to riparian vegetation. If plant species are both rare and preferred forage for beavers (e.g. cottonwood) a discharge above this threshold will promote higher rates of foraging on this plant. Managers should be cognizant of this relationship and be willing to protect these species during such events.

\section{ACKNOWLEDGEMENTS}

The US Geological Survey and the Denver Zoological Foundation funded this research. We thank personnel from the National Park Service and Cross Mountain Ranch for permission to work on the Yampa River, and personnel from Browns Park National Wildlife Refuge for permission to work on the Green River and for the assistance they provided. We thank A. Craig, S. Pavey, M. Andre, D. Neubaum and C. Nesnow for assistance in the field, and G. Reese for assistance with the GIS applications. T. Hobbs and J. Detling provided constructive reviews of the manuscript. 


\section{REFERENCES}

Akaike H. 1973. Information theory as an extension of the maximum likelihood principle. In Second International Symposium on Information Theory, Petrov BN, Csaki F (eds). Akademiai Kiado: Budapest, Hungary.

Andersen DC, Cooper DJ. 2000. Plant-herbivore-hydroperiod interactions: effects of native mammals on floodplain tree recruitment. Ecological Applications 10: 1383-1399.

Andrews ED. 1986. Downstream effects of Flaming Gorge Reservoir on the Green River, Colorado and Utah. Geological Society of America Bulletin 97: 1012-1023.

Augustine DJ, McNaughton SJ. 1998. Ungulate effects on the functional species composition of plant communities: herbivore selectivity and plant tolerance. Journal of Wildlife Management 62: 1165-1183.

Baker BW, Cade BS. 1995. Predicting biomass of beaver food from willow tree diameters. Journal of Range Management 48: 322-326. Barnes WJ, Dibble E. 1988. The effects of beaver in riverbank forest succession. Canadian Journal of Botany 66: 40-44.

Basey JM, Jenkins SH. 1995. Influences of predation risk and energy maximization on food selection by beavers (Castor canadensis). Canadian Journal of Zoology 73: 2197-2208.

Braatne JH, Rood SB, Heilman PE. 1996. Life history, ecology, and conservation of riparian cottonwoods in North America. In Biology of Populus and its Implications for Management and Conservation, Stettler RF, Bradshaw HD Jr, Heilman PE, Hinckley TM (eds). NRC Research Press, National Research Council of Canada: Ottawa; 57-85.

Bradley CE, Smith DG. 1986. Plains cottonwood recruitment and survival on a prairie meandering river floodplain, Milk River, southern Alberta and northern Montana. Canadian Journal of Botany 64: 1433-1442.

Breck SW. 2001. The effects of flow regulation on the population biology and ecology of beavers in northwestern Colorado. Dissertation, Colorado State University, Fort Collins.

Breck SW, Wilson KR, Andersen DC. 2001. The demographic response of bank-dwelling beavers to flow regulation: a comparison on the Green and Yampa rivers. Canadian Journal of Zoology 79: 1957-1964.

Buckland ST, Burnham KP, Augustin NH. 1997. Model selection: An integral part of inference. Biometrics 53: 603-618.

Burnham KP, Anderson DR. 1998. Model Selection and Inference: a Practical Information-Theoretic Approach. Springer-Verlag: New York.

Busch DE, Smith SD. 1995. Mechanisms associated with decline of woody species in riparian ecosystems of the southwestern U.S. Ecological Monographs 65: 347-370.

Cooper DJ, Merritt DM, Andersen DC, Chimner RA. 1999. Factors controlling the establishment of Fremont cottonwood seedlings on the Upper Green River, USA. Regulated Rivers: Research and Management 15: 419-440.

Doucet C, Fryxell J. 1993. The effect of nutritional quality on forage preference by beavers. Oikos 67: 201-208.

Fenner P, Brady WW, Patton DR. 1985. Effects of regulated water flows on regeneration of Fremont Cottonwood. Journal of Range Management 38: $135-138$.

Fryxell JM. 1992. Space use by beavers in relation to resource abundance. Oikos 64: 474-478.

Fryxell JM. 1999. Functional responses to resource complexity: an experimental analysis of foraging by beavers. In Herbivores: Between Plants and Predators, Olff H, Brown VK, Drent RH (eds). Blackwell Science: Malden, Massachusetts; 371-396.

Fryxell JM, Doucet CM. 1993. Diet choice and the functional response of beavers. Ecology 74: 1297-1306.

Gessaman JA, MacMahon JA. 1984. Mammals in ecosystems: their effects on the composition and production of vegetation. Acta Zoologica Fennica 172: 11-18.

Gill D. 1971. The evolution of a discrete beaver habitat in the Mackenzie River Delta, Northwest Territories. Canadian Field-Naturalist 86: $233-239$.

Gregory SV, Swanson FJ, McKee WA, Cummins KW. 1991. An ecosystem perspective of riparian zones. BioScience 41: 540-551.

Hilborn R, Mangel M. 1997. The Ecological Detective: Confronting Models with Data. Princeton University Press: Princeton, New Jersey.

Hobbs TH. 1996. Modification of ecosystems by ungulates. Journal of Wildlife Management 60: 695-713.

Holling CS. 1959. The components of predation as revealed by a study of small mammal predation of the European pine sawfly. Canadian Entomology 91: 293-320.

Howe WH, Knopf FL. 1991. On the imminent decline of Rio Grande cottonwoods in central New Mexico. Southwestern Naturalist 36: $218-224$.

Huntly N. 1991. Herbivores and the dynamics of communities and ecosystems. Annual Review of Ecology and Systematics 22: 477-503. Jenkins SH. 1980. A size-distance relation in food selection by beavers. Ecology 61: 740-746.

Johnston CA, Naiman RA. 1990. Browse selection by beaver: effects on riparian forest composition. Canadian Journal of Forest Resources 20: 1036-1043.

Knopf FL, Johnson RR, Rich T, Samson FB, Szaro R. 1988. Conservation of riparian ecosystems in the United States. Wilson Bulletin 100: $272-284$.

Krebs CJ. 1996. Population cycles revisited. Journal of Mammalogy 77: 8-24.

Krebs CJ, Boonstra R, Kenney AJ. 1995. Population-dynamics of the collared lemming and the tundra vole at pearce-point, NorthwestTerritories, Canada. Oecologia 103: 481-489.

Lebreton JD, Burnham KP, Colbert J, Anderson DR. 1992. Modeling survival and testing biological hypotheses using marked animals: a unified approach with case studies. Ecological Monographs 62: 67-118.

Lesica P, Miles S. 1999. Russian olive invasion into cottonwood forests along a regulated river in north-central Montana. Canada Journal of Botany 77: 1077-1083. 
McGinley MA, Whitham TG. 1985. Central place foraging by beavers (Castor canadensis): a test of foraging predictions and the impact of selective feeding on the growth form of cottonwoods (Populus fremontii). Oecologia 66: 558-652.

Merritt DM, Cooper DJ. 2000. Riparian vegetation and channel change in response to river regulation: a comparative study of regulated and unregulated streams in the Green River Basin, USA. Regulated Rivers: Research \& Management 16: 543-564.

Morgan RA, Brown JS, Thorson JM. 1997. The effect of spatial scale on the functional response of fox squirrels. Ecology 78 : $1087-1097$.

Naiman RJ, Rogers KH. 1997. Large animals and system-level characteristics in river corridors. Implications for river management. BioScience 47: 521-529.

Nolet BA, Hoekstra A, Ottenheim MM. 1994. Selective foraging on wood species by the beaver Castor fiber, and its impact on a riparian willow forest. Biological Conservation 70: 117-128.

Reily PW, Johnson WC. 1982. The effects of altered hydrologic regime on tree growth along the Missouri River in North Dakota. Canadian Journal of Botany 60: 2410-2423.

Rood SB, Mahoney JM. 1995. River damming and riparian cottonwoods along the Marias River, Montana. Rivers 5: 195-207.

Scott ML, Friedman JM, Auble GT. 1996. Fluvial processes and the establishment of bottomland trees. Geomorphology 14: 327-339.

Scott ML, Auble GT, Friedman JM. 1997. Flood dependency of cottonwood establishment along the Missouri River, Montana, USA. Ecological Applications 7: 677-690.

Segelquist CA, Scott ML, Auble GT. 1993. Establishment of Populus deltoides under simulated alluvial groundwater declines. American Midland Naturalist 130: 274-285.

Sokal RR, Rohlf FJ. 1981. Biometry. W. H. Freeman: San Francisco.

Snyder WD, Miller GC. 1992. Changes in riparian vegetation along the Colorado River and RioGrande, Colorado. Great Basin Naturalist 52: $357-363$.

Stanford JA, Ward JV, Liss WJ, Frissell CA, Williams RN, Lichatowich JA, Coutant CC. 1996. A general protocol for restoration of regulated rivers. Regulated Rivers: Research and Management 12: 391-413.

Stromberg JC, Patten DC, Richter BD. 1991. Flood flows and dynamics of Sonoran riparian forests. Rivers 2: 221-235.

Strong PIV. 1982. Beaver-cottonwood interactions and beaver ecology in Big Bend National Park. MS Thesis, Oklahoma State University, Stillwater, OK.

White GC, Burnham KP. 1999. Program MARK: survival estimation from populations of marked animals. Bird Study 46(Supplement): $120-139$. 